\title{
The Metaphors of Secondary School Teachers Towards the Concept of "Multiculturalism"*
}

\author{
Emine Karasu Avc1 ${ }^{1}$, Melike Faiz ${ }^{1}$ \\ ${ }^{1}$ Faculty of Education, Kastamonu University, Kastamonu, Turkey \\ Correspondence: Melike Faiz, Faculty of Education, Kastamonu University, Kastamonu, Turkey.
}

Received: March 1, 2018

Accepted: April 9, 2018

Online Published: April 21, 2018

doi:10.11114/jets.v6i5.3066

URL: https://doi.org/10.11114/jets.v6i5.3066

\begin{abstract}
In this research, it is aimed to reveal the perceptions which teachers from various branches and performing duty in secondary schools have, concerning the concept of multiculturalism, through metaphors. As one of the qualitative research methods, phenomenological design has been used in the research. The study group of the research is composed of 70 teachers who worked in the secondary schools located in Kastamonu Province and its districts in the academic year 2016-2017, and voluntarily accepted to participate in the research. Within the scope of the research, data has been obtained by asking teachers to complete the statement: Multiculturalism is like ...; because .... The collected data has been analyzed by means of descriptive analysis. In the research, it has been concluded that teachers generally have positive perceptions related to the multiculturalism concept. Teachers consider the concept of multiculturalism mostly as a sense embracing differences and riches, with the metaphors which they have already enhanced. Besides, in the research, a negative result regarding multiculturalism as a divisive factor has been also received. As for the metaphors that the teachers have mainly developed, these are the metaphors of rainbow, forest, riches, jigsaw puzzle, food, garden, Noah's pudding, synthesis and change.
\end{abstract}

Keywords: multiculturalism, secondary school teacher, metaphor

\section{Introduction}

Multiculturalism has changed the outlook for the entire world, with the economic crisis such as famine, hunger, unemployment, rising prices, inflation broke out during the first and second world wars, transnational and cross-continental migrations encountered, and the emerging changes in the fields of communication and transportation. The world has divided into two, as Europe and America, and the ethnic groups have started to gather round these two areas. As a natural outcome, the cultures gathered around have interacted. Yet, at times, this interaction has also brought about an adaptation issue. Thus, multiculturalism has come to the fore at many countries' agenda in the century we are going through. With both its positive and negative aspect, it has changed the basis for countries. In this regard, it will be to the point to explain the concept of culture before looking deep into multiculturalism concept with such great importance.

Parekh (2000) defined culture as the system of meaning and significance created within the historical process, a system of belief and practice which enables a group of human beings to understand, regulate and structure their own individual and also collective lives. Clyde Kluckholn stated that culture was "a design for living" and determined the behavioral patterns for individuals as the members of a certain community (Williams, 1986). Turkish Language Association (2018), in its online dictionary, defined the culture as a whole of means which is used in establishing all material and moral values created in the historical and social development process, in conveying these to the next generations and which demonstrates the extent of human dominance on his natural and social environment. Duverger (2004) described culture as organized behaviors, thoughts and emotions which totally designate the behaviors and roles expected from a community. According to Kymlicka (1995), being affiliated to a culture means a context of choice and a reliable sense of identity and belonging that are referred in order to give an answer to the questions related to personal values and intentions. Beside this, it has been stated that human communities within each society develop different cultures as based on their common past, the region in which they live, their economic attempts and practices, and socio-economic

\footnotetext{
*This study was presented as an oral presentation International Social Studies Education Symposium VI.
} 
status (Cırık, ,2008). Also, Polat and Kılıç (2013) asserted that there were several factors having an effect on culture, culture differentiated within the same society by the virtue of various factors and different sub-cultures would be able to arise from the same culture. Based on these definitions and statements, we can define culture as individual and collective lives that various communities have, behaviors expected from the one included in a specific community, their shared and/or common past, economic practices and social status. Culture varies according to different societies and the concept of multiculturalism appears upon the coexistence of these societies.

Although the concept of multiculturalism was used in Switzerland in 1957 for the first time, in consequence of the rise in social diversity in the United States of America, Canada and Europe in the 1960s, it emerged in the 1970s, with the fact that civil rights movements and ethnic minorities and also women concentrated upon equal right and opportunity and following that racism, sexism and oppression directed to these groups were brought to notice (Başbay and Bektaş, 2009, Sengstock, 2009, Lambert, Moghaddam, Sorin and Sorin, 1990). The concept of multiculturalism varies by different viewpoints. Sue, Arredando and McDavvis (1992) pointed out that culture, by and large, existed in race, ethnicity, class, affectional orientation, religion, sex, age and so forth. They also stated that multiculturalism was shaped according to racial and ethnic diversity and to gender and private groups, as well. Özensel (2012) expressed that societies developed identities proper to themselves within the scope of value judgments and behavior patterns they had. This identity principally contains the concept of difference in itself. As for the concept of "difference" underlying identity formation, it has its own value system. Multiculturalism has originated from the unification of these different identities. According to Lambert et al. (1990), people from any ethnicity tried to prevent themselves from being socially or politically assimilated and conserved their authenticity as far as possible. Each part of the mosaic, existing on the same geography and constituting the components of the common heritage, developed the concept of culture and led to the multiculturalism concept. Multiculturalism is to enable different cultures to be conserved, different identities to be maintained and also enhanced. Ideologically and theoretically, multiculturalism can bear different meanings, as a part of social structure. The concept, additionally, involves various senses and/or meanings such as the expression of cultural differences in public realm, bestowing special rights upon minorities, the preservation, maintenance and advancement of different cultures and identities which the minorities themselves have, and encouraging the development of different cultural structures (Başbay and Bektaş, 2009).

Based on these definitions, it has been seen that multiculturalism originated as a result of migrations; however, in recent years, the outcomes which globalization brought in its wake have evolved and introduced multiculturalism as a crucial phenomenon for developing countries. In this sense, multiculturalism not only is a sociological concept, but also is a concept important to several disciplines such as economics, psychology and so on. Multiculturalism is also influential in shaping the sense of education of the societies. In the systems of education with a multicultural perspective, attaching importance to individual differences, treating every individual equally and taking the social and cultural environment in which individuals lead their lives into consideration are on the basis. In the studies carried out as regard to multiculturalism, positive and negative opinions are included together. Çetin (2005) makes a comparison between multiculturalism and a garden with flowers in different colors, and with this comparison, emphasizes riches accompanied by the multiculturalism. Levi-Strauss (2007) related the diversity of cultures to the bonds and relations uniting them, rather than a disintegrating or dissected analysis and the isolation of their communities from each other.

Statement of the problem is to determine the metaphor of secondary school teachers' multiculturalism. In recent years, in Turkey, the concept of multiculturalism has become more of an issue as Turkey reached the condition of an immigrant-receiving country. Because recently, largely as a result of war held in Turkey's border it has been migrated to Turkey. These migrations changed the structure of society. Therefore, the perceptions of multiculturalism by the teachers who shape the society are very important. Hence, the necessity of the formation of a mosaic texture reveals. It is required for teachers who are the practitioners of education systems to be able to integrate the concept of multiculturalism into the system. Therefore, that teachers have a viewpoint concerning multiculturalism is essential. Within the scope of this study, multiculturalism is going to be dealt with from its positive aspect.

\subsection{Objective of the Research}

The objective of this research is to reveal the perceptions which teachers from different branches (Turkish, Mathematics, Social Studies, Science and Technology, Psychological Counseling and Guidance, English, Religious Culture and Moral Knowledge, Physical Training, Painting, Music, Information Technologies) and employed in secondary schools have towards the concept of multiculturalism, through metaphors. Metaphor stands for the symbolic expressions which a concept arouses in an individual's mind. It is the endeavor made by an individual to explain a concept with another one (Eraslan, 2011). In this research, metaphor has been approached as the case of teachers' explaining the concept of multiculturalism with another concept. Accordingly, the problem statement of this research has been determined as "What are teachers' metaphors for the concept of multiculturalism?" 


\section{Method}

\subsection{Research Model}

In this research, phenomenological design which is one of the qualitative research methods has been employed. Phenomenology is described as the qualitative research model which deals with an individual's or individuals' experiences related to a phenomenon (Creswell, 2016). Seeing that teachers answer the research question by benefiting from their own experiences, phenomenological research design has been preferred in the research.

\subsection{Study Group}

The study group of research consists of 70 teachers from different branches (Turkish, Mathematics, Social Studies, Science and Technology, Psychological Counseling and Guidance, English, Religious Culture and Moral Knowledge, Physical Training, Painting, Music, Information Technologies), who were working in the secondary schools in Kastamonu Province and its districts in the 2016-2017 academic year and accepted to participate in the research voluntarily. For this reason, convenience sampling has been used in the research. Convenience sampling can be explained as a means by which the researcher includes individual or individuals easy-to-reach in the research process (Yıldırım and Şimşek, 2016).

Table 1. Frequency and Percentage Distribution of Secondary School Teachers by Branches

\begin{tabular}{lll}
\hline Branches & Frequency & Percentage \\
\hline Science & 10 & 14,28 \\
Social Studies & 2 & 2,85 \\
Turkish & 7 & 10 \\
Mathematics & 9 & 12,85 \\
Religious Culture and Moral Knowledge & 8 & 11,42 \\
Information Technologies & 10 & 14,28 \\
Painting & 1 & 1,42 \\
Physical Training & 2 & 2,85 \\
Music & 5 & 7,14 \\
Psychological Counseling and Guidance & 12 & 17,14 \\
English & 4 & 5,71 \\
TOTAL & 70 & 100 \\
\hline
\end{tabular}

According to Table 1, the branch of Psychological Counseling and Guidance constitutes the majority of secondary school teachers participated in the research $(\mathrm{f}=12,17,14 \%)$. It is followed by the branch of Science $(\mathrm{f}=10,14,28 \%)$ and Information Technologies ( $\mathrm{f}=10,14,28 \%)$. Mathematics $(\mathrm{f}=9,12,85 \%)$ and Religious Culture and Moral Knowledge $(\mathrm{f}=8,11,42 \%)$ also follow the other branches. As for the branches taking part in the research with the fewest number, these are Social Studies $(\mathrm{f}=2,2,85 \%)$ and Physical Training $(\mathrm{f}=2,2,85 \%)$.

\subsection{Collection of Data}

In this research, as a means of data collection, teachers serving in secondary schools have been asked to complete the statement: Multiculturalism is like ...; because .... A period of time at the length of 10-15 minutes has been allowed for the teachers to be able to think enough and complete the sentence. 70 feedbacks in total have been received from the teachers holding different branches (Turkish, Mathematics, Social Studies, Science and Technology, Psychological Counseling and Guidance, English, Religious Culture and Moral Knowledge, Physical Training, Painting, Music, Information Technologies). In the research, the notion of "because" is included and so, teachers have been asked to put forward a reason for their own metaphors. Findings obtained from seven teachers have been considered invalid since more than one metaphor was created and metaphors without reason were formed. Findings received from 63 teachers have been considered valid. These gathered findings have constituted the main data source of the research. Answers given by the teachers have been kept confidential by the researchers and not been shared with anyone.

\subsection{Analysis and Interpretation of Data}

Data obtained within the scope of research have been analyzed by means of descriptive analysis. Descriptive analysis is the method of analysis in which obtained data are organized according to pre-determined category or themes and direct quotes from the participants are included (Yıldırım and Şimşek, 2016). Also, the metaphors developed by the teachers in this research have been categorized by having benefitted from the study titled "Metaphoric Perceptions of Faculty Members' Regarding Multicultural Education" by Günay, Aydın and Koç Damgacı (2015). Each metaphor has been grouped within the scope of conception referred from the source of metaphor in the explanations teachers have come up with. Data have been analyzed as based on the stages of analysis made by Yıldırım and Şimşek (2016): 


\subsubsection{Forming a Frame for Descriptive Analysis}

It is the stage at which data are organized on the basis of the theoretical framework of the study. In this research, at first, various codes were presented to the teachers participating in the research. For instance, codes like F.B.Ö.1. (Science Teachers-1) were produced. Same codifications were also carried out on the basis of other branches in the same way. Afterwards, metaphors which teachers participating in the research had already developed were evaluated and analyzed, and listed by being numbered in alphabetical order. Work sheets which no metaphor was used in, more than one metaphor was applied in and were left blank were excluded from the scope of research.

\subsubsection{Treatment of Themes by Thematic Framework}

At this stage of the study, data are read and organized in accordance with the framework previously specified. In this study also, data obtained by benefiting from the study belonging to Günay, Aydın and Koç Damgacı (2015) have been classified into 5 categories. At that stage, metaphors were analyzed in terms of the subject of metaphor, the source of metaphor and traits regarded to be referred from the source of metaphor; and then, common grounds of metaphors were detected and placed into the relevant categories. Following that, all data were computerized in frequency (f) and percentages $(\%)$.

\subsubsection{Description of Findings}

Data organized at this stage are supported by direct quotes. At that stage of the research, through data obtained from the teachers, findings were tried to be described by having direct quotes belonging to teachers from different branches included in, under the title of relevant categories.

\subsubsection{Interpretation of Findings}

At this stage, the clarification, association and interpretation of findings are carried out. Cause and effect relation is established among findings. Comparison between different phenomena is made. Similarly, in this research, findings obtained have been explained and interpreted by the researchers, as based on the cause-effect relation established.

\subsection{Limitations}

This research is limited to;

- Kastamonu Province,

- Teachers who serve in secondary schools,

- Forming metaphor which is related to the concept of "Multiculturalism".

\subsection{Validity and Reliability}

Validity and reliability are regarded as two significant criteria that enable credibility in researches. In this research, validity has been tried to be guaranteed by the explanation of the analysis process of gathered data in a comprehensive manner and the direct involvement of the opinions unique to the prospective teachers in the description of findings (Yıldırım and Şimşek, 2016). With the aim of enabling reliability in the research, analyzer triangulation has been actualized. Analyzer triangulation is stated as two or more people's analyzing the data separately and comparing the findings obtained (Patton, 2014). For the purpose of ensuring the reliability of study, the two researchers taking their parts in the study (Social Studies Education, Faculty Members) have been asked for their opinions. The researchers have come together and reached agreement on the points they dissented from.

\section{Findings}

In this part of the research, metaphors that secondary school teachers from various branches have formed with regard to the concept of "multiculturalism" are presented in the lists and interpreted. Teachers' metaphors concerning multiculturalism have been divided into 5 different categories by referring to the study "Metaphoric Perceptions of Faculty Members' Regarding Multicultural Education" carried out by Günay, Aydın and Koç Damgacı (2015). Metaphors obtained in the research were placed into these categories.

Table 2. Categories formed regarding the concept of "Multiculturalism"

\begin{tabular}{lll}
\hline Categories & $\mathrm{f}$ & $\%$ \\
\hline Embracing Differences and Considering as Riches & 74 & 72,54 \\
\hline One and the Same Root in the Past & 12 & 11,76 \\
\hline Equality of Opportunity & 8 & 7,84 \\
\hline Divisive & 8 & 7,84 \\
\hline Total & 102 & 100 \\
\hline
\end{tabular}

Metaphors which teachers developed for multiculturalism have been placed into categories mentioned above. Among 
the categories formed, the one in which the highest number of metaphors is generated is the category of "embracing differences and considering as riches" ( $\mathrm{f}=74)$. This category is followed by the ones "considering as riches" ( $\mathrm{f}=12$ ) and "one and the same root in the past" ( $\mathrm{f}=12$ ). Metaphors pertaining to these categories are involved in Table 2, Table 3, Table 4, Table 5 and Table 6.

Table 3. Metaphors that secondary school teachers developed for the category of embracing differences and considering as riches

\begin{tabular}{llllll}
\hline Name of Metaphor & $\mathrm{f}$ & $\%$ & Name of Metaphor & $\mathrm{f}$ & $\%$ \\
\hline 1.Rainbow & 9 & 12 & 23.White light & 1 & 1,33 \\
2.Forest & 5 & 6,66 & 24.Color palette & 1 & 1,33 \\
3.Riches & 4 & 5,33 & 25.Assorted nuts & 1 & 1,33 \\
4.Jigsaw puzzle & 3 & 4 & 26.Patterns of the same science & 1 & 1,33 \\
5.Food & 3 & 4 & 27.Noah's ark & 1 & 1,33 \\
6.Garden & 3 & 4 & 28.Oil on-canvas painting & 1 & 1,33 \\
7.Noah's pudding & 3 & 4 & 29.Funfair & 1 & 1,33 \\
8.Synthesis & 3 & 4 & 30.Football team & 1 & 1,33 \\
9.Tree & 2 & 2,66 & 31.Community & 1 & 1,33 \\
10.Human anatomy & 2 & 2,56 & 32.A bunch of grapes & 1 & 1,33 \\
11.Five fingers of hand & 2 & 2,56 & 33.Sliced apple & 1 & 1,33 \\
12.Unity of perception & 2 & 2,56 & 34.Snowball & 1 & 1,33 \\
13.Computer & 2 & 2,56 & 35.Harmony & 1 & 1,33 \\
14.Variety & 2 & 2,56 & 36.Success & 1 & 1,33 \\
15.Mixed ice cream & 1 & 1,33 & 37.Modernization & 1 & 1,33 \\
16.Bee getting benefit from flower & 1 & 1,33 & 38.Gain & 1 & 1,33 \\
17.Piquent sauce & 1 & 1,33 & 39.Enlightenment & 1 & 1,33 \\
18.Pizza & 1 & 1,33 & 40.The Black Sea & 1 & 1,33 \\
19.Ocean & 1 & 1,33 & 41.Enjoying the life to the full & 1 & 1,33 \\
20.Cake & 1 & 1,33 & 42.English & 1 & 1,33 \\
21.Shepherd salad & 1 & 1,33 & 43.Gold & 1 & 1,33 \\
22.Musical instrument & 1 & 1,33 & 44.Chameleon & 1 & 1,33 \\
Total & & & & 74 & 100 \\
\hline
\end{tabular}

According to Table 3, the teachers participating in the research have already developed 44 metaphors related to the category of embracing differences and considering as riches. This indicates that teachers have different points of view for the concept of multiculturalism. Furthermore, it can be interpreted that teachers have positive views for this concept, as based on the fact that they have developed more metaphors related to the category of embracing differences and considering as riches, of all categories. When these metaphors are analyzed, it is seen that rainbow ( $\mathrm{f}=9$ ), forest $(\mathrm{f}=5$ ), riches ( $\mathrm{f}=4$ ), jigsaw puzzle $(\mathrm{f}=3)$, food $(\mathrm{f}=3)$, garden $(\mathrm{f}=3)$, Noah's pudding $(\mathrm{f}=3)$ and synthesis $(\mathrm{f}=3)$ are the metaphors generated at most. Samples for the descriptions made by teachers in regard to the metaphors developed for this category are presented in the following:

T.T.1. "Multiculturalism is like the Black Sea; because it accepts to embody everything."

M.T.2. "Multiculturalism is like rainbow; because differences are nice all in one."

P.T.1. "Multiculturalism is like riches; because it is the process of enculturation in interaction with several different cultures."

S.T.5. "Multiculturalism is like jigsaw puzzle; because the whole cannot be formed if a part is missing."

P.C.G.T.4. "Multiculturalism is like mixed ice cream; because every culture is unique and favored for itself."

I.T.T.5. "Multiculturalism is like pizza; because taste enhances as the ingredients increase." 
E.T.8. "Multiculturalism is like riches; because sharing and accumulation of knowledge and experiences among people create a social richness."

When the answers that teachers have produced for the metaphors are analyzed, it can be stated that they emphasized the differences; yet, they evaluated these differences as an integrative and holistic factor. It can be also said that teachers have opinions indicating that differences are good, multiculturalism involves the common ground, it will enhance the culture, parts will constitute a whole, different cultures provide other cultures with benefits.

Table 4. Metaphors that secondary school teachers developed for the category of one and the same root in the past

\begin{tabular}{lll}
\hline Name of Metaphor & f & $\%$ \\
\hline 1.Forest & 5 & 41,66 \\
2.Life & 2 & 16,66 \\
3.Heritage & 1 & 8,33 \\
4.Tree & 1 & 8,33 \\
5.Different history & 1 & 8,33 \\
6.Water spring/source & 1 & 8,33 \\
7.Step & 1 & 8,33 \\
Total & 12 & 100 \\
\hline
\end{tabular}

According to Table 4, it is seen that 7 metaphors have been formed for the category of having one and the same root in the past. It is found that the metaphors teachers have developed for this category as related to the concept of multiculturalism are less. This situation can be commented in the way that teachers associate the relevant concept with the past less. Upon analyzing Table 4, metaphors produced most have been the ones for forest ( $\mathrm{f}=5$ ) and life ( $\mathrm{f}=2$ ). As for the other metaphors developed, they were generated by only one teacher. Samples for the descriptions made by teachers in regard to the metaphors developed for this category are presented below:

I.T.T.7. "Multiculturalism is like life; because it turns the world into a small town, it differentiates our view of life by ensuring that we both know ourselves and the others."

R.C.M.K.T.6. "Multiculturalism is like a tree; because its root is one and the same but the leaves on its branches are different."

P.C.G.T 2. "Multiculturalism is like a step; because each step represents a different part from the life."

When the samples for the metaphors which teachers have formed for this category are analyzed, it can be said that teachers think the concept of multiculturalism is passed down by being nourished from the past, and is the bridge for novelty and development.

Table 5. Metaphors that secondary school teachers developed for the category of equality of opportunity

\begin{tabular}{lll}
\hline Name of Metaphor & $\mathrm{f}$ & $\%$ \\
\hline 1.Tolerance & 2 & 25 \\
2.Sun & 2 & 25 \\
3.Sharing & 1 & 12,5 \\
4.Flat-mateship & 1 & 12,5 \\
5.Norm & 1 & 12,5 \\
6.Scale & 1 & 12,5 \\
Total & 8 & 100 \\
\hline
\end{tabular}

When Table 5 is analyzed, it is seen that teachers have formed six metaphors for the category of equality of opportunity, concerning multiculturalism. It can be interpreted that teachers regard the concept of multiculturalism as the equality of opportunity to a lesser extent, as based on the result that they have formed less metaphors for this category. As for the metaphors produced at most concerning this category, these are the ones of tolerance $(\mathrm{f}=2)$ and sun $(\mathrm{f}=2)$. Samples for the descriptions made by teachers in regard to the metaphors developed for this category are specified below:

T.T.4. "Multiculturalism is like tolerance; because respect to different life styles is shown."

I.T.T.9. "Multiculturalism is like sharing; because individuals in the society are always in interaction."

S.T.1. "Multiculturalism is like flat-mateship; because a common ground is found every time."

P.C.G.T.1. "Multiculturalism is like equality; because many cultures dominate a region equally."

M.T.4. "Multiculturalism is like norm; because norms are required for people to understand each other."

Concerning this category, it is seen that the teachers attach importance to having respect to different lives, being able to meet on common ground and acting in accordance with the norms, by putting emphasis on the concepts such as tolerance, sharing, friendship, and equality. 
Table 6. Metaphors that secondary school teachers developed for the category of divisive

\begin{tabular}{lll}
\hline Name of Metaphor & f & $\%$ \\
\hline 1.Change & 3 & 37,5 \\
2.Chaos & 1 & 12,5 \\
3.Thread (a fine wire) & 1 & 12,5 \\
4.African violet & 1 & 12,5 \\
5.Chemical product & 1 & 12,5 \\
6.Lawbreakers in traffic & 1 & 12,5 \\
Total & 8 & 100 \\
\hline
\end{tabular}

When analyzed, Table 6 shows that teachers have developed six metaphors pertaining to the category of divisive. Teachers have formed fewer metaphors for the category of divisive. This case can be interpreted in the way that teachers actually do not perceive the concept of multiculturalism as a negative condition that is like divisiveness. Teachers most emphasize the metaphor of change ( $\mathrm{f}=3$ ) as related to the category of divisive. Samples for the descriptions made by teachers, concerning the metaphors developed for this category, are presented below:

S.S.T.1. "Multiculturalism is like change; because change may not lead to development."

S.T.2. "Multiculturalism is like African violet; because everything is plainer and uniform in mono-cultural societies."

I.T.T.4. "Multiculturalism is like chaos; because war environment is possible to occur if each culture has a tendency to think itself superior and exercise influence over another one."

M.T.6. "Multiculturalism is like the lawbreakers in traffic; because it is difficult to be respectful and to show empathy towards one another in traffic."

When the answers that teachers have produced for the metaphors are analyzed, it is understood that they have stated multiculturalism would be able to represent a divisive factor. At this point, teachers have argued that it would be possible for dominant cultures to harm the other ones, it would be difficult to acknowledge that culture as different cultures were encountered, and people would consider their own cultures superior.

\section{Discussion and Conclusion}

Within the scope of this research, it has been concluded that teachers generally have positive perceptions towards the concept of multiculturalism. Through the metaphors they have already developed, teachers participating in the research regard multiculturalism as a concept embracing differences and as richness. In addition, they assess the concept of multiculturalism as a component that has had one and the same root in the past and also enables equality of opportunity. Beside this, a negative result concerning multiculturalism as a divisive factor has been obtained in the research. In the study by Polat and Kılıç (2013), the importance of teachers' perception in the practices for multiculturalism was pointed out. Demir (2012), in her study in which she had analyzed the importance degree of multicultural education according to faculty members, ascertained that faculty members attached importance to multicultural education. In the study carried out by Damgacı and Aydin (2013), the result indicating that academicians' attitudes towards multicultural education were positive was reached. It was determined that the levels of attitudes pre-service teachers adopted for multiculturalism and multicultural education were both positive and negative in the study by Ünlü and Örten (2013). In the study which Bulut and Başbay (2015) carried out, teachers' senses of competency for multiculturalism were dealt with. Accordingly, it was determined in the research that teachers were competent at the level of awareness, knowledge and skill. In the study by Günay, Aydın and Koç Damgacı (2015), that the most of academicians serving in faculties of education exhibited a positive attitude concerning the concept of multiculturalism has been seen. In the literature review, through the studies carried out (Arslan, 2016; Tonbuloğlu, Aslan and Aydın, 2016; Bahadır, 2016; Akar, 2017), it is seen that teachers and pre-service teachers have positive views of multiculturalism and multicultural education. Alismail (2016) raised concern over the importance of a multicultural understanding in order that teachers could meet the cultural diversity in their classrooms. In the study by Özcan (2018), it is stated that MEB (The Ministry of National Education) has been pursuing a positive education policy for Syrian students, within the context of multicultural education. Çetin (2005) has established a similarity between multiculturalism and a garden with flowers in different colors, and with this comparison, emphasized the richness multiculturalism brings with. Levi-Strauss (2007) relates the diversity of cultures to the bonds and relations uniting them, rather than a disintegrating or dissected analysis and the isolation of their communities from each other. In the studies within the literature, it can be stated that the teachers, pre-service teachers and academicians have positive views for the concept of multiculturalism in general terms. The results of the studies in literature as related to the views and attitudes towards multiculturalism concept, which teachers, pre-service teachers and academicians have adopted, show similarity to the results obtained from this research.

It is seen that the metaphors which teachers have mainly produced for multiculturalism as related to the category of embracing differences and considering as riches are composed of the metaphors of rainbow, forest, richness, jigsaw 
puzzle, food, garden, Noah's pudding and synthesis. When the sources of thought for the metaphors teachers have already developed are analyzed, it can be stated that they emphasize the differences related to the concept of multiculturalism; however, they consider these differences as a unifying and holistic component. To the category of being rooted in the past, the metaphors of forest and life are the ones they have formed most. Considering the sources of thought for the metaphors teachers have formed for this category, it is seen that they have opinions implying that the concept of multiculturalism is conveyed from one generation to the next as being nourished from the past and this concept establishes a bridge of innovation and advancement. The metaphors that teachers have mostly produced for the category of equality of opportunity, concerning multiculturalism, are the ones of tolerance and sun. When the bases for thought related to this category are analyzed, it is understood that teachers consider respecting to different lives, meeting on a common ground and acting in compliance with the norms important, by placing emphasis on the concepts such as tolerance, sharing, mateship, and equality. Başbay and Bektaş (2009), in their study, underline that the ones who exhibit positive attitudes towards multiculturalism have a sense in the way that multiculturalism secures individual differences and creates cultural richness. This concept's being regarded as a cultural richness reveals that it is similar in terms of the result obtained from this research. In the study carried out by Ünlü and Örten (2013), pre-service teachers have adopted positive attitudes towards the concept of multiculturalism for certain reasons such as the inception of living together and maintenance of peace environment and allowing everyone experience his or her own culture. In Mapuranga and Bukaliya's study (2014), most of the teachers stated that they were performing practices for multicultural education. In the study by Başarır, Sarı and Çetin (2014), teachers put forward that they were practicing multicultural education in their classes and that education was proper to different cultures and ensured the principle for equality of opportunity. Also, in this research, the concept of multiculturalism participants evaluated the terms of equality of opportunity, and it has been emphasized that differences should be enjoyed and experienced by everyone equally. Furthermore, the participants also indicated unity and solidarity while emphasizing the importance of differences. In the study by Günay, Aydın and Koç Damgacı (2015), academicians related multicultural education mainly to the metaphors of rainbow, mosaic, flower garden, orchestra, hodgepodge, rug and Noah's pudding. Within the scope of the study carried out by Öksüz, Güven Demir and İci (2016), teachers and pre-service teachers dealt with the concept of multicultural education mostly with regards to its enabling the richness that differences create. In addition to this, teachers and pre-service teachers have associated multicultural education concept mainly with the metaphors of food and Noah's pudding. In this research, teachers have developed the metaphors of rainbow, forest and richness at most, without taking categories into consideration. From the studies in literature and this research, it is found out that the metaphors developed concerning the concept of multiculturalism give point to the differences. In this context, it can be stated that educators notice the differences related to multiculturalism concept; however, they consider these differences as a constituent that strengthens unity and solidarity.

The metaphor that teachers have mostly produced for the category of divisive is the metaphor of change. Considering the sources of thought which teachers have in relation to this category are analyzed, they have specified the reasons for their seeing multiculturalism as divisive by referring to such cases in which dominant cultures might damage the other ones, it might be difficult to admit this culture since different cultures are encountered with, and people might consider their own cultures superior. Başbay and Bektaş (2009) stated that negative opinions for multiculturalism were also underlined in their study. They implied that the ones who objected to that sense held the view asserting that multiculturalism damaged social unification. In the study carried out by Ünlü and Örten (2013), pre-service teachers had negative attitudes towards the concept of multiculturalism, with the views implying that cultural differences would cause a state of chaos and lead to some segregations. In the study carried out by Günay, Aydın and Koç Damgacı (2015), academicians produced the metaphor of chaos for multicultural education. It was seen that teachers and pre-service teachers perceived the concept of multicultural education as a threat to social unity, in the study carried out by Öksüz, Güven Demir and İci (2016). Teachers and pre-service teachers have thought that the atmosphere of peace and tranquility in the society would be disturbed by multicultural education and it might cause separations and/or divisions in the country. In the same manner, that Social Studies teachers had perceptions in the direction that multiculturalism would be able to cause divisions was presented in the study carried out by Bahadır (2016). The studies in literature are such as to give a support for the result obtained from this research, according to which multiculturalism is perceived as a divisive factor. On the contrary, Cirı (2008) underlined that it is required for us not to regard multiculturalism as a divisiveness factor, but to see it as our strengths originated from our differences. When seen from different points of view, multiculturalism both points to the necessity for differences to be considered important as a matter of democracy and is perceived as a threatening factor in terms of the unity and solidarity of the countries. Yet, by taking the results obtained from this research and also the findings presented in the literature into the consideration together, it can be said that educators have positive views for this concept.

The reason why the concept of multiculturalism is studied in the literature is the formation of multicultural society structures with the migration due to the wars that have taken place in the last century. Turkey is one of the countries 
affected by this situation. The education of the children of different societies by the education system and teachers of another country is a situation in which a multicultural society has emerged. As in many countries, there are many students who are in this situation in Turkey. All of these make it necessary to investigate the concept of multiculturalism and provide for the study of teacher, student and parent dimensions in order to develop multicultural education systems.

\section{Suggestions}

With the ever-changing social structure, the concept of multiculturalism has become particularly important. In order that people can live together in a good agreement with each other, especially for students, courses for multiculturalism may be included in all of the grades in curriculum system, as of primary school level, and seminars may be conducted.

This research has been carried out with the participation of teachers who undertake education activities at the level of secondary school. Similar researches intended for the ones who teach at different educational stages may be conducted.

It has been seen that the concept of multiculturalism is generally perceived in a positive manner by the educators in our country. These educators explain multiculturalism mostly by the concepts related to citizenship such as cultural richness, equality, and respect to differences. In this sense, studies dealing with the relation between multiculturalism and citizenship can be carried out.

In Turkey, at times, the concept of multiculturalism is regarded as a threatening and divisive factor, as well. Views concerning that multiculturalism might be disruptive for social integrity and unity have been put forward as reason for this. In this context, while conducting studies on multiculturalism in Turkey, it is necessary to take this sensitivity into consideration.

\section{References}

Akar, C. (2017). The predictive level of preservice classroom teachers' multicultural values of critical thinking disposition. Ahi Evran University Kırşehir Faculty of Education Journal (KEFAD), 18(1), 741-762.

Alismail, H. A. (2016). Multicultural education: Teachers' perceptions and preparation. Journal of Education and Practice, 7(11), 139-146.

Arslan, S. (2016). Multicultural education and turkey: current situation, prospects, possibilities. Electronic Journal of Social Sciences, 15(57), 412-428.

Bahadır, Ö. (2016). The evaluation of social science teachers' multiculturalism and their multi-cultural education perception. Unpublished Master Thesis, Sakarya University Educational Sciences Institute, Sakarya.

Başarır, F., Sarı, M., \& Çetin, A. (2014). Examination of Teachers' Perceptions of Multicultural Education. Pegem Journal of Education and Instruction, 4(2), 91-110. https://doi.org/10.14527/pegegog.2014.011

Başbay, A., \& Bektaş, Y. (2009). Instructional Environment and Teacher Competences in the Context of Multiculturalism. Education and Science, 34(152), 30-43.

Bulut, C., \& Başbay, A. (2015). Determination of teachers' multicultural competence percaptions. K.Ü. Kastamonu Education Journal, 23(3), 957-978.

Çetin, İ. (2005). In the wealth of urban culture ethnic diversitiy: A sample of Midyat. Unpublished Master Thesis. Ege University Social Sciences Institute.

Cirık, İ. (2008). Multıcultural education and its reflections. H. U. Journal of Education,34, 27-40.

Creswell, J. C. (2016). Nitel Araştırma Yöntemleri. 3.Translation from the press, Mesut Bütün, Selçuk Beşir Demir (Çev. Ed.), Ankara: Siyasal Kitabevi.

Damgac1, F., \& Aydın, H. (2013). Attitudes of the academicians towards multicultural education. Electronic Journal of Social Sciences, 12(45), 325-341.

Demir, S. (2012). Importance degree of multicultural education according to Erciyes University faculty members. Electronic Turkish Studies, 7(4), 1453-1475. https://doi.org/10.7827/TurkishStudies.3871

Duverger, M. (2004). Siyaset sosyolojisi. (Ş. Tekeli, Çev.). İstanbul: Varlık Yayınları.

Eraslan, L. (2011). Sociological metaphors. Academic Overview International Journal of Social Sciences, 27, 1-22.

Günay, R., Aydın, H., \& Koç, D. F. (2015). Metaphoric Perceptions of Faculty Members' Regarding Multicultural Education. Cankiri Karatekin University Journal of Institute of Social Sciences Çankırl Karatekin Üniversitesi Sosyal Bilimler Enstitüsü Dergisi, 6(1), 291-312.

Kymlicka, W. (1995). Multicultural citizenship: A liberal theory of minority rights. Clarendon Press.

Lambert, W. E., Moghaddam, F. M., Sorin, J., \& Sorin, S. (1990, September). Assimilation vs. multiculturalism: Views 
from a community in France. In Sociological Forum (Vol. 5, No. 3, pp. 387-411). Springer Netherlands. https://doi.org/10.1007/BF01115093

Levi-Strauss, C. (2007). Irk, tarih, kültür, Translated: Haldun Bayrı, Reha Erdem, Arzu Oyacıoğlu, Işık Ergüden, İstanbul: Metis Yayınları.

Mapuranga, B., \& Bukaliya, R. (2014). Multiculturalism in schools: An appreciation from the teachers' perspective of multicultural education in the Zimbabwean school system. International Journal of Humanities Social Sciences and Education, 1(2), 30-40.

Öksüz, Y., Güven Demir, E., \& İci, A. (2016). Examining metaphors of teachers and teacher candidates towards concept of multicultural education. Electronic Journal of Social Sciences, 15(59), 1263-1278.

Özcan, A. S. (2018). Turkey's education policy towards syrian students in the context multiculturalism. PESA International Journal of Social Studies, 4(1), 1-15.

Özensel, E. (2012). Multiculturalism as the application multiculturalism Canada. Journal of Academic Inquiries, 7(1), 55-70.

Parekh, B. C. (2000). Rethinking multiculturalism: cultural diversity and political theory. United Kingdom: Macmillian Press Ltd.

Patton, M. Q. (2014). Nitel araştırma ve değerlendirme yöntemleri. Mesut Bütün, Selçuk Beşir Demir (Translated Ed.), 3. Translation from the Press, Ankara: Pegem Akademi Yayıncıllk.

Polat, İ., \& Kılıç, E. (2013). Multicultural education in Turkey and teacher's competencies in multicultural education. YYÜ Journal of Education Faculty, 10(1), 352-372.

Sengstock, M. C. (2009). Voices of diversity: Multi-culturalism in America. Springer Science \& Business Media. https://doi.org/10.1007/978-0-387-89666-3

Sue, D. W., Arredondo, P., \& McDavis, R. J. (1992). Multicultural counseling competencies and standards: A call to the profession. Journal of Counseling \& Development, 70(4), 477-486. https://doi.org/10.1002/j.1556-6676.1992.tb01642.x

Tonbuloglu, B., Aslan, D., \& Aydin, H. (2016). Teachers' awareness of multicultural education and diversity in school settings. Eurasian Journal of Educational Research, 16(64). https://doi.org/10.14689/ejer.64.1

Türk Dil Kurumu Güncel Sözlük (2018). Kültür. retrieved at 28.01.2018 from http://www.tdk.gov.tr/index.php?option=com_gts\&arama=gts\&guid=TDK.GTS.5a67820798c243.09764176

Ünlü, İ., \& Örten, H. (2013). Investigation the perception of teacher candidates about multiculturism and multicultural education. Dicle University Journal of Ziya Gökalp Faculty of Education, 21, 287-302.

Williams, M. (1986). Society today. London: Macmillian Education. https://doi.org/10.1007/978-1-349-08845-4

Yıldırım, A., \& Şimşek, H. (2016). Sosyal Bilimlerde Nitel Araştırma Yöntemleri. 10. Baskı, Ankara: Seçkin Yayıncılık.

\section{Copyrights}

Copyright for this article is retained by the author(s), with first publication rights granted to the journal.

This is an open-access article distributed under the terms and conditions of the Creative Commons Attribution license which permits unrestricted use, distribution, and reproduction in any medium, provided the original work is properly cited. 